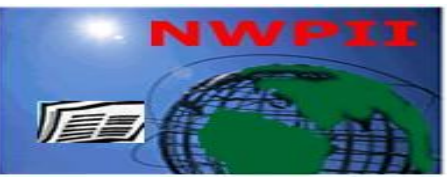

American Journal of Biomedical Sciences

ISSN: 1937-9080

nwpii.com/ajbms

\title{
Geranylgeranylacetone Induces HPS70 and Protects Cochlear Tissues from in Vitro Acute Noise Trauma
}

\author{
Abeer A. Shoman MD*, Mona Maher MD \\ Department of physiology,Faculty of Medicine Benha University,Egypt \\ *Corresponding Author \\ Abeer Ahmed Shoman \\ Department of physiology \\ Faculty of Medicine Benha University \\ Egypt \\ Tel: +00201007297790 \\ Email: shoman_abeer@yahoo.com
}

Received:04 May 2019; | Revised:26 May 2019; | Accepted:21 December 2019

\begin{abstract}
Objectives: Evaluation of effect of 7-day prophylactic use of Geranylgeranylacetone (GGA) before acute noise exposure (ANE) on rat cochlear tissue homogenate (CTH) levels of HSP 70, malondialdehyde (MDA), and activity of antioxidant enzymes and find a relation between CTH and serum levels of HSP70.

Materials \& Methods: Thirty-two male albino rats divided into 4 equal groups: Group I received no prophylaxis or exposure to noise, Group II exposed to a $115 \mathrm{~dB}$ octave band noise centered at $4 \mathrm{kHz}$ for $6-\mathrm{h}$ without prophylaxis, Group III and IV included animals received GGA (600 mg/kg/day for 7 days) without noise exposure or before exposure, respectively, to noise as for group II. Twenty-four hours after noise exposure, blood samples were taken from all animals for estimation of serum levels of HSP 70. Then, animals were sacrificed and skull was opened immediately for extraction of both cochleas that were homogenized for estimation for levels of HSP 70, MDA and activity of antioxidants.

Results: MDA content was significantly higher, but levels and activities of antioxidant enzymes were significantly lower in CTH of group II than other groups. Mean CTH levels of HSP70 were significantly higher in animals of Group IV compared to other groups and in Group II compared to groups I and III with non-significantly higher levels in Group III than Group I. Serum HSP70 levels were significantly higher in Group IV than other groups and in Group II than group I. In control group, there was positive significant correlation $(r=0.893, p=0.003)$ between HSP 70 serum and CTH levels.

Conclusion: ANT induces cochlear tissue oxidative stress; however, prophylactic GGA therapy could ameliorate this effect through increasing cochlear tissue HSP70 expression levels. ELISA estimation of serum HSP70 levels could reflect its tissue levels and could be used as non-invasive diagnostic modality for impact of stresses.
\end{abstract}

Keywords: Geranylgeranylacetone, HSP 70, Acute noise exposure, Cochlear tissue, Oxidative stress 


\section{Introduction}

Sound is an important part of man's contact with the environment and has served as critical means for survival throughout his evolution [1]. Noise, one of the main components of modern society, has become an important environmental problem ${ }^{[2]}$. Noise is not only an irritating sound, but also a stress factor leading to serious health problems ${ }^{[3]}$. Acute loud noises or chronic noise exposure in social and working environments can cause noise-induced hearing loss ${ }^{[4]}$, which is emerging as a global health problem that affects over $5 \%$ of the population worldwide ${ }^{[5]}$.

Exposure to intense sound can produce temporary threshold shifts, acute changes in hearing sensitivity that recover over time ${ }^{[6]}$. Noise exposure level of 115-125 dB SPL induces mechanical damage, while exposure level of less than $115 \mathrm{~dB}$ SPL induces metabolic damage ${ }^{[7]}$.

Heat shock proteins (HSPs), a family of polypeptide proteins consisting of several members, perform important housekeeping functions and are named according to their molecular weight ${ }^{[8]}$. HSP represent an important element in the body's defense against various damaging factors ${ }^{[9]}$. Exposure to stressful stimuli activates a transient induction of the $70 \mathrm{kDa}$ heat shock protein (HSP70) ${ }^{[10]}$. HSP70 chaperones and their co-chaperones comprise a set of abundant cellular machines, which plays critical roles in protein homeostasis in almost all cellular compartments ${ }^{[11]}$. HSP70 protects cells and tissues from different pathological conditions ${ }^{[12]}$, so its expression is rarely detected in cells under normal growth conditions ${ }^{[13]}$, but is highly induced under physiological and environmental stresses ${ }^{[14]}$.

Geranylgeranylacetone (GGA), an acyclic polyisoprenoid compound, is a derivative of terpenes with a molecular formula of $\mathrm{C} 23 \mathrm{H} 38 \mathrm{O}$. GGA protects a variety of cells and tissues against numerous stresses via induction of HSP70 ${ }^{[15]}$. GGA has gastromucoprotective effect, but its prophylactic administration markedly inhibited the development of diclophenac-induced lesions in small intestine [16]. GGA significantly reversed cerebral ischemia/reperfusion increased neurological function abnormality, brain edema, inflammation and oxidative injury in rats in a dose-dependent manner ${ }^{[17]}$. Prophylactic GGA helps to suppress the onset and progression of retinitis pigmentosa as a result of its ability to prevent HSP70 degradation [18].

Hypothesis:

Acute noise trauma affects cochlear biochemical milieu mostly the oxidant/antioxidant one and induces other changes in protective molecules, so the prophylactic use of certain drugs may modify these effects.

Aim of work:

Evaluation of the effect of 7-day prophylactic use of GGA before acute noise exposure on rat cochlear tissue homogenate levels of HSP 70, malondialdehyde (MDA), and activity of antioxidant enzymes. Also, the study tried to find a relation between cochlear tissue homogenate and serum levels of HSP70.

\section{Materials and Methods}

The current prospective comparative study was conducted at Department of Physiology, Faculty of Medicine, Benha University since March till July 2016. The study protocol was approved by the Local Ethical Committee, Benha Faculty of Medicine.

\subsection{Animals}

The present study included 32 male albino rats with weight range of 250-300 grams obtained from Faculty of Vet Medicine, Moshtohor, Benha University. Rats were grouped and kept in separate animal cages, under the prevailing atmospheric conditions and room temperature. Animals were maintained on a balanced diet and fresh-water supply with light/dark cycle till start of the study. At the end of the experiment and after collection of the samples we got rid of the animals in the incinerator of Benha University Hospital.

\subsection{Experiment Design}

Animals were divided into 4 equal groups $(n=8)$ according to the medications received and noise exposure:

1-Group I included animals maintained in normal environment without exposure to noise as negative control group. 
2-Group II included animals exposed to a 115 $\mathrm{dB}$ octave band noise centered at $4 \mathrm{kHz}$ for $6-\mathrm{h}^{[19]}$ without any prophylactic premedication as a positive control group.

3-Group III included animals pretreated with single daily dose of geranylgeranylacetone (GGA; Selbex; Sigma Aldrich; Germany) at $600 \mathrm{mg} / \mathrm{kg}$ for 7 days before sampling without noise exposure.

4-Group IV included animals pretreated with single daily dose of GGA (600 mg/kg for 7 days) before exposure to noise as for group II. GGA was emulsified and prepared in 5\% gum arabic and $0.6 \%$ Tween 80 for every administration to ensure a fresh suspension ${ }^{[20]}$.

\subsection{Noise exposure}

White noise was obtained by using the broadband noise $\mathrm{CD}$ (whitenoisemp3s.com/freewhite-noise). It was intensified using a $40-\mathrm{W}$ amplifier and octave band noise centered at $4 \mathrm{kHz}$ at a root-mean square level of $115 \mathrm{~dB}$ sound pressure level and was transmitted from speakers that were placed $30 \mathrm{~cm}$ away from the cage. The intensity of $115 \mathrm{~dB}(\mathrm{~A})$ was chosen because it reflects the common noise level in industrial workplaces and entertainment centers ${ }^{[2]}$.

\subsection{Blood and Tissue sampling}

Twenty-four hours after noise exposure, all animals were anaesthetized with urethane $(1.5 \mathrm{~g} / \mathrm{kg}$; i.p.) and blood sample was taken aseptically by cardiac puncture. Then, animals were sacrificed by decapitation, skull was immediately opened, hold on side so the 'bowl' of the skull is facing up to identify the temporal bone that lies in the back and is not continuous to the skull, the junctions between the skull and the temporal bone (away from the cochlea area) were pushed to break it away from skull and extraneous bones were dissected (Fig. 1). To assure of cochlear extraction, using a magnifying lens, temporal bone grasped so that apex of cochlea is up (at index finger) and vestibule of temporal bone is down (at thumb), round and oval windows were identified at a line of junction between cochlea and vestibule (Fig. 2) ${ }^{[21]}$.

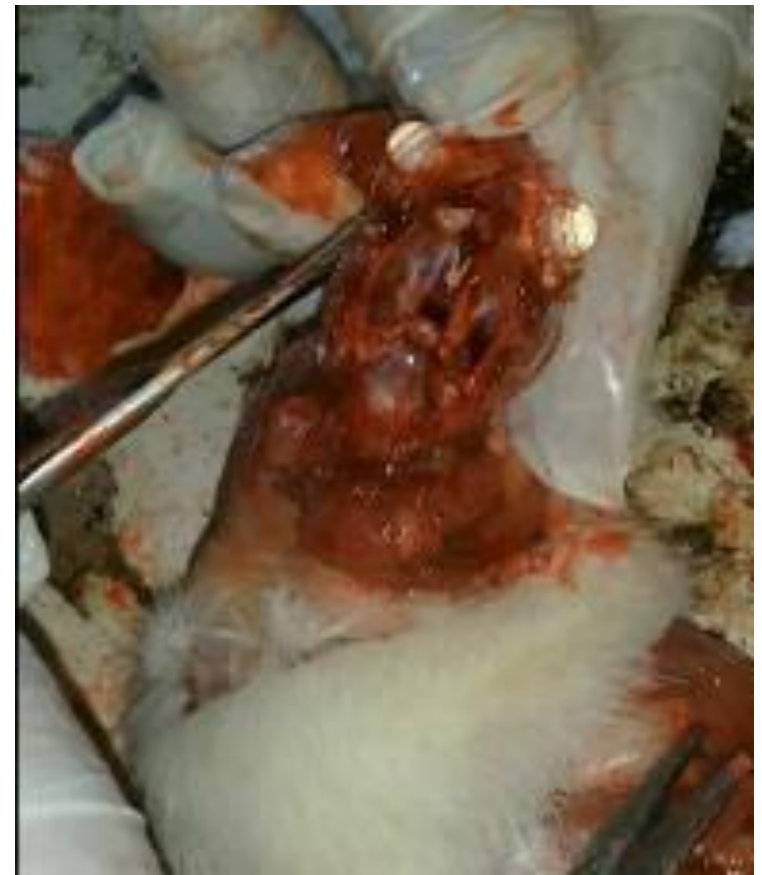

Figure 1: showing the base of the rat skull after removal of the crown and the whole brain tissue, during extraction of the cochlea

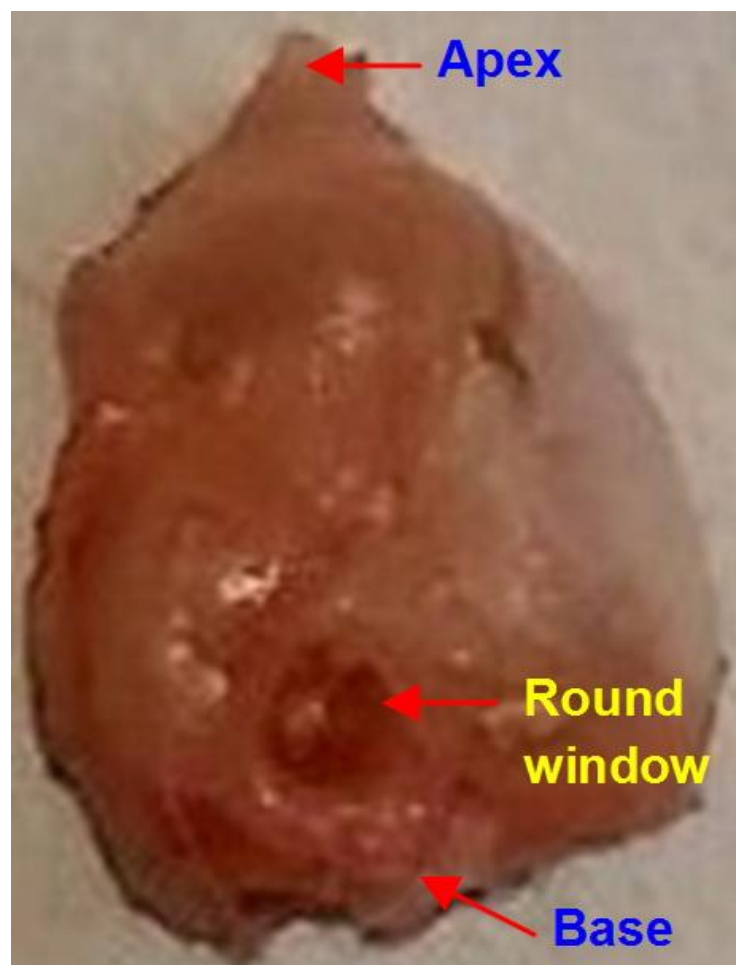

Figure 2: showing the extracted cochlea with its apex up, base down and foramen oval is shown 


\subsection{Samples preparations and Investigations}

A)Blood samples were placed in a centrifuge tube, allowed to clot and centrifuged for 10 minutes at $6000 \mathrm{rpm}$. Serum was separated in clean Eppendorf tube and stored at $-20^{\circ} \mathrm{C}$ till being assayed.

B)Extracted cochlear tissue was rinsed immediately in ice-cold PBS $(0.02 \mathrm{~mol} / \mathrm{L}, \mathrm{pH} 7.0$ 7.2) to remove excess blood thoroughly, divided into two parts and each was and weighed before homogenization:

1.The 1st part was homogenated in ice-cold $0.1 \mathrm{M}$ phosphate-buffered saline (PBS) at $\mathrm{pH} \mathrm{7.4,}$ the homogenate was centrifuged at $10,000 \times \mathrm{g}$ for 10 minutes and kept at $-20^{\circ} \mathrm{C}$ until being prepared and assayed for estimation of antioxidant activity levels and malondialdhyde (MDA) content.

2.The 2nd part was minced into small pieces and homogenized in 5-10 $\mathrm{ml}$ of PBS with a glass homogenizer on ice, the resulting suspension was subjected to two freeze-thaw cycles to further break the cell membranes, homogenates were centrifuged for 5 minutes at $5000 \mathrm{x} \mathrm{g}$ and supernatant was store at $-20^{\circ} \mathrm{C}$ till being assayed for estimation of cellular HSP70 level.

\subsection{Investigations}

A)The prepared homogenate of the $1^{\text {st }}$ part was divided into three parts:

-The $1^{\text {st }}$ part was deproteinized with ice-cooled $12 \%$ trichloroacetic acid, centrifuged at $1000 \mathrm{x} \mathrm{g}$. Supernatant was separated and stored at $-20^{\circ} \mathrm{C}$ till be assayed for estimation of reduced glutathione (GSH) activity using Cayman GSH assay (Cayman Chemical Co., Ann Arbor, MI, USA) ${ }^{[22]}$.

-The $2^{\text {nd }}$ part was centrifuged at $1600 \times \mathrm{g}$ for $10 \mathrm{~min}$ at $4^{\circ} \mathrm{C}$. Supernatant was separated and stored at $-80^{\circ} \mathrm{C}$ till be assayed for estimation of malondialdhyde (MDA) content using Cayman
Thiobarbituric Acid Reactive Substances assay (Cayman Chemical Co., Ann Arbor, MI, USA) ${ }^{[23]}$.

-The $3^{\text {rd }}$ part of the homogenate was used to prepare a cytosolic fraction of the cochlear tissue by centrifugation at $10,000 \mathrm{xg}$ for $15 \mathrm{~min}$ at $4^{\circ} \mathrm{C}$ using a cooling ultra-centrifuge (Sorvall Combiplus $\mathrm{T}$ 880, Du Pont, USA). The obtained clear supernatant (cytosolic fraction) was used for the colorimetric estimation of glutathione peroxidase (GPx) ${ }^{[24]}$, catalase (CAT) ${ }^{[25]}$ and superoxide dismutase (SOD) [26] activity using Cayman assays (Cayman Chemical Co., Ann Arbor, MI, USA).

B)The prepared homogenate of the $2^{\text {nd }}$ part of cochlear tissue and serum samples were ELISA assayed for serum HSP70 using in vitro Simple Step ELISA ${ }^{\circledR}$ kit (Abcam Biochemicals, Victoria, Bristol, UK) designed for the quantitative measurement of HSP70 protein in human cell and tissue extract samples ${ }^{[27]}$.

\subsection{Statistical analysis}

Obtained data were presented as mean $\pm \mathrm{SD}$, ranges, numbers and ratios. Results were analyzed using One-way ANOVA with post-hoc Tukey HSD Test. Statistical analysis was conducted using the SPSS (Version 15, 2006) for Windows statistical package. $\mathrm{P}$ value $<0.05$ was considered statistically significant.

\section{Results}

Cochlear tissue homogenate (CTH) MDA content was significantly $(\mathrm{P}=0.001)$ higher in group II compared to levels estimated in CTH of other groups with non-significant $(\mathrm{p}>0.05)$ differences between MDA levels estimated in CTH of groups I, III and IV. On the other hand, estimated SOD, CAT, GSH and GPx enzyme activities in CTH were significantly $(\mathrm{P}=0.001)$ lower in group II compared to other groups with non-significant $(\mathrm{p}>0.05)$ difference between groups I, III and IV (Table 1, Fig. 3). 
Table 1: Mean $( \pm$ SD) levels of studied parameters estimated in cochlear tissue homogenate of animals of studied groups

\begin{tabular}{|l|c|c|c|c|}
\hline \multicolumn{1}{|c|}{ Group } & \multicolumn{1}{|c|}{$\begin{array}{c}\text { Group I } \\
\text { (No } \\
\text { prophylaxis or } \\
\text { Noise) }\end{array}$} & $\begin{array}{c}\text { Group II } \\
\text { (No } \\
\text { prophylaxis }+ \\
\text { Noise) }\end{array}$ & $\begin{array}{c}\text { Group III } \\
\text { (GGA } \\
\text { prophylaxis no } \\
\text { Noise) }\end{array}$ & $\begin{array}{c}\text { Group IV } \\
\text { (GGA } \\
\text { prophylaxis }+ \\
\text { Noise) }\end{array}$ \\
\hline $\begin{array}{l}\text { MDA content } \\
\text { (mmol/g wet tissue) }\end{array}$ & $40 \pm 8.1$ & $136 \pm 15.2$ & $41.5 \pm 6.5^{*}$ & $52 \pm 10.8^{*}$ \\
\hline $\begin{array}{l}\text { SOD activity level } \\
\text { (mmol/g wet tissue) }\end{array}$ & $57 \pm 12$ & $31 \pm 10.6$ & $54.4 \pm 10.1^{*}$ & $51 \pm 6^{*}$ \\
\hline $\begin{array}{l}\text { CAT activity level } \\
\text { (mmol/ g wet tissue) }\end{array}$ & $24.5 \pm 6.6$ & $11.5 \pm 4.5$ & $22.5 \pm 4.4^{*}$ & $22 \pm 3.3^{*}$ \\
\hline $\begin{array}{l}\text { GSH activity level } \\
\text { (mmol/g wet tissue) }\end{array}$ & $31.16 \pm 2$ & $21.7 \pm 2.3$ & $29.13 \pm 1.42^{*}$ & $28 \pm 2^{*}$ \\
\hline $\begin{array}{l}\text { GPx activity level } \\
\text { (U/ g wet tissue) }\end{array}$ & $1958 \pm 80.8$ & $1049 \pm 79$ & $1857 \pm 105^{*}$ & $1758 \pm 140^{*}$ \\
\hline
\end{tabular}

Data are presented as mean \pm SD; MDA: Malondialdehyde; GSH: reduced glutathione; GPx: glutathione peroxidase;

CAT: Catalase; SOD: superoxide dismutase; * indicates significant difference versus group II

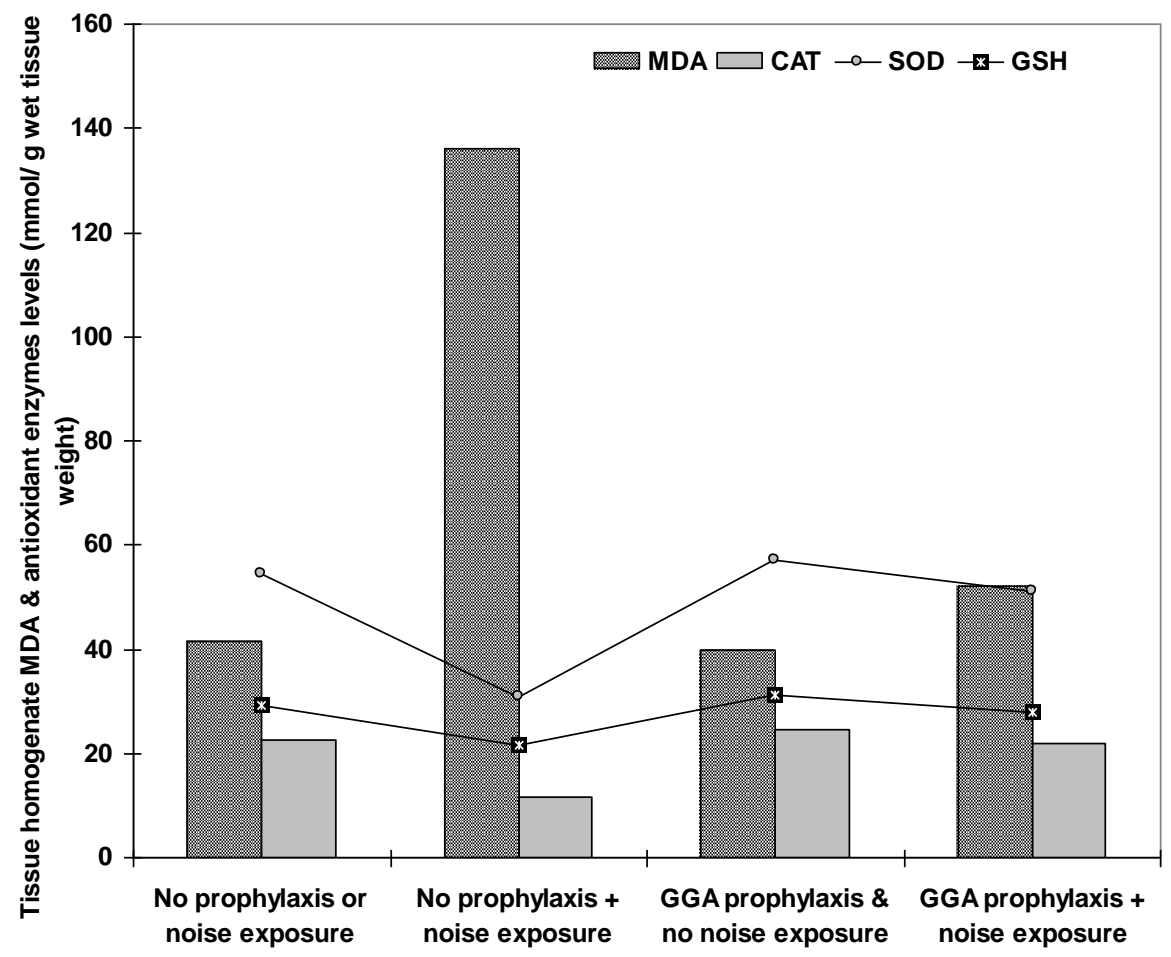

Figure 3: Mean MDA levels and antioxidant enzymes activity levels estimated in cochlear tissue homogenate of animals of studied groups

Mean CTH levels of HSP70 were significantly higher in animals of Group IV that were prepared by GGA and exposed to acute noise trauma (ANT) compared to levels estimated in animals of other groups. Interestingly, mean HSP70 levels estimated in $\mathrm{CTH}$ of animals exposed to ANT without preparation (Group II) was significantly higher than levels estimated in animals of groups I and III. GGA preparation induced HSP70 expression as evidenced by non-significantly higher levels in CTH of animals of group III compared to that of animals of group I (Table 2, Fig. 4).

Similarly, mean serum HSP70 levels were significantly higher in animals of Group IV 
compared to levels estimated in animals of other groups. However, mean serum HSP70 levels estimated animals of Group II were significantly higher compared to levels estimate $d$ in animals of group I, but non-significantly higher than levels estimated in serum of animals of groups III. Moreover, HSP70 levels estimated in serum of animals of Group III were non-significantly higher than levels estimated in serum of animals of Group I (Table 2, Fig. 5).

In control group that did not receive any form of prophylaxis nor exposed to ANT, there was a positive significant correlation $(\mathrm{r}=0.893, \mathrm{p}=0.003)$ between serum and CTH levels of HSP70, (Fig. 6).

Table 2: Mean $( \pm$ SD) levels of HSP70 estimated in cochlear tissue homogenate and serum of animals of studied groups

\begin{tabular}{|c|c|c|}
\hline $\begin{array}{c}\text { Group } \\
\text { Parameter }\end{array}$ & CTH & Serum \\
\hline Group I (No prophylaxis or Noise) & $112.4 \pm 9.4$ & $328 \pm 109.6$ \\
\hline Group II (No prophylaxis + Noise) & $185.8 \pm 17.22^{*}$ & $707.5 \pm 169.3^{*}$ \\
\hline Group III (GGA prophylaxis + no Noise) & $127.6 \pm 13.1 \dagger$ & $526.3 \pm 95$ \\
\hline Group IV (GGA prophylaxis + Noise) & & \\
& $210 \pm 18.6^{*} \dagger \dagger$ & $1253.5 \pm 245.2^{*} \dagger \ddagger$ \\
\hline
\end{tabular}

* indicates significant difference versus group I; $\uparrow:$ indicates significant difference versus group II; $\$$ indicates significant difference versus group III

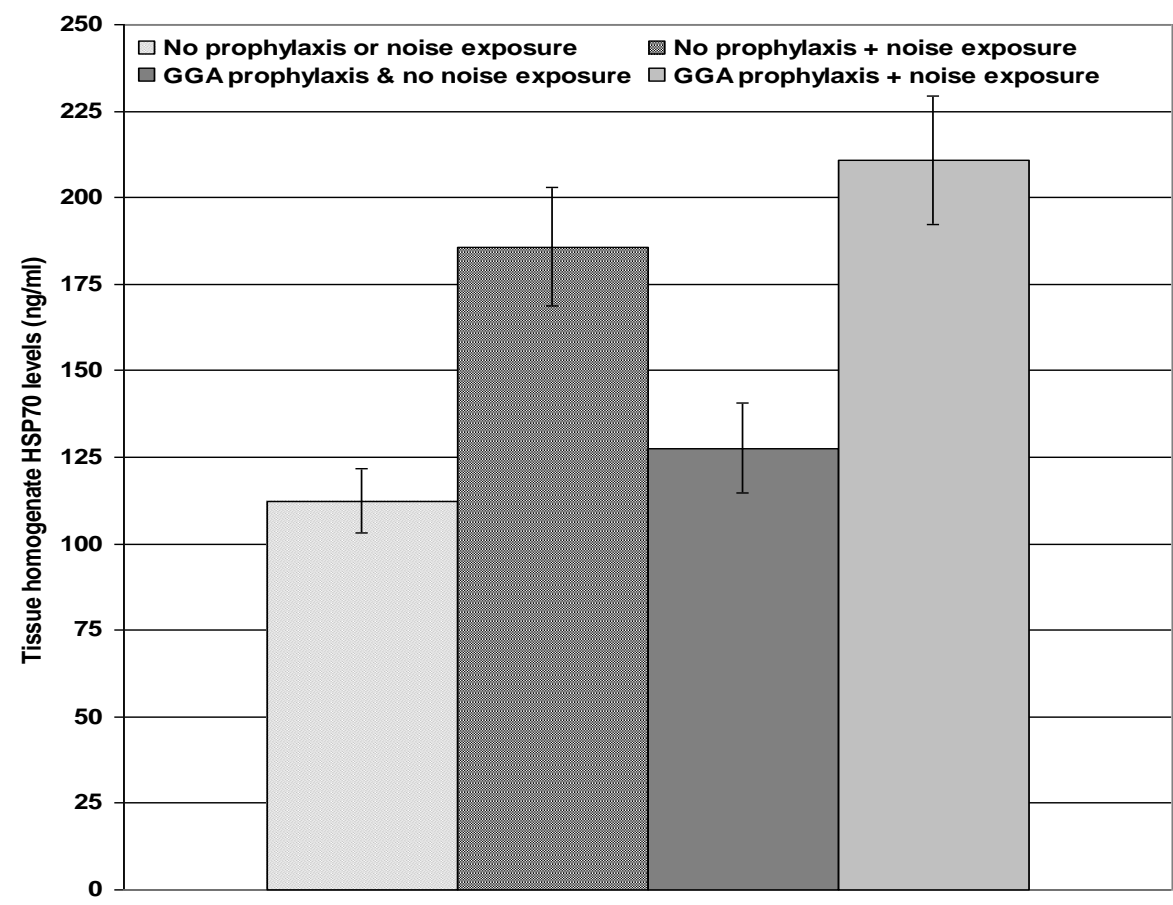

Figure 4: Mean $( \pm$ SD) cochlear tissue homogenate HSP70 levels estimated in animals of studied groups 


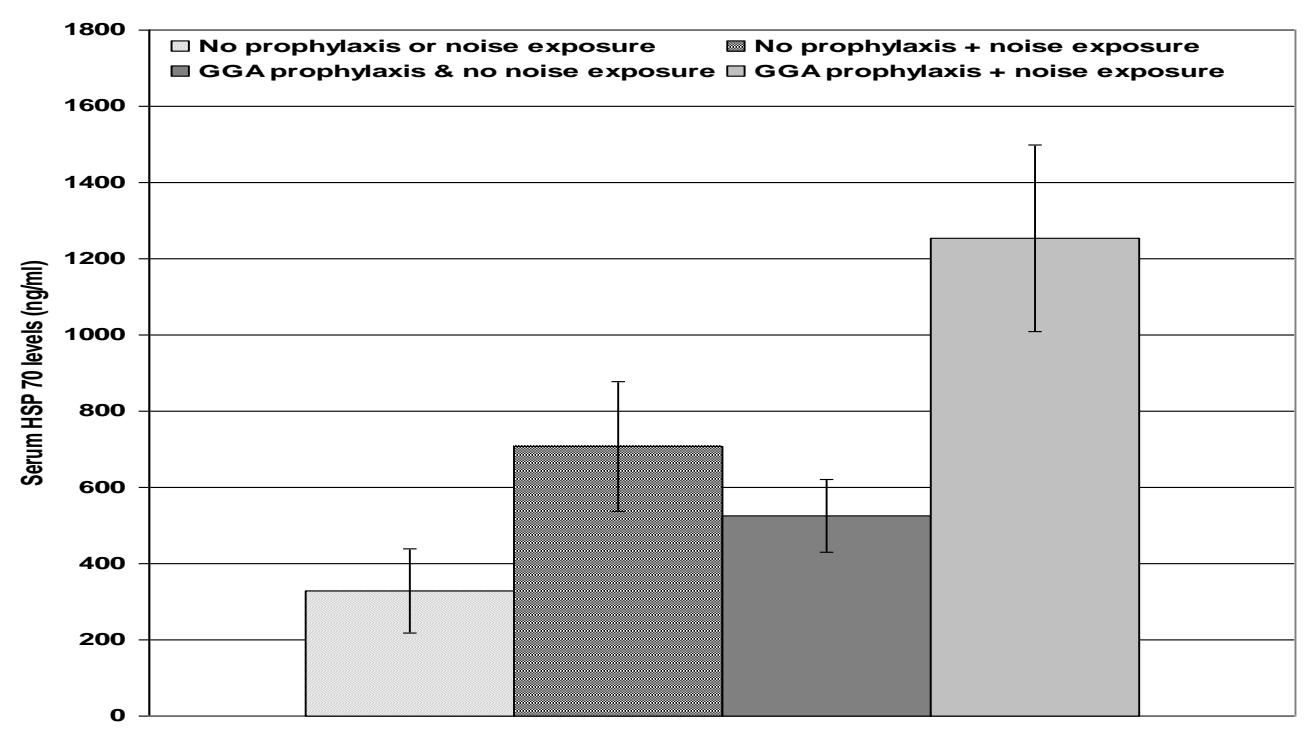

Figure 5: Mean $( \pm \mathrm{SD})$ serum HSP70 levels estimated in animals of studied groups

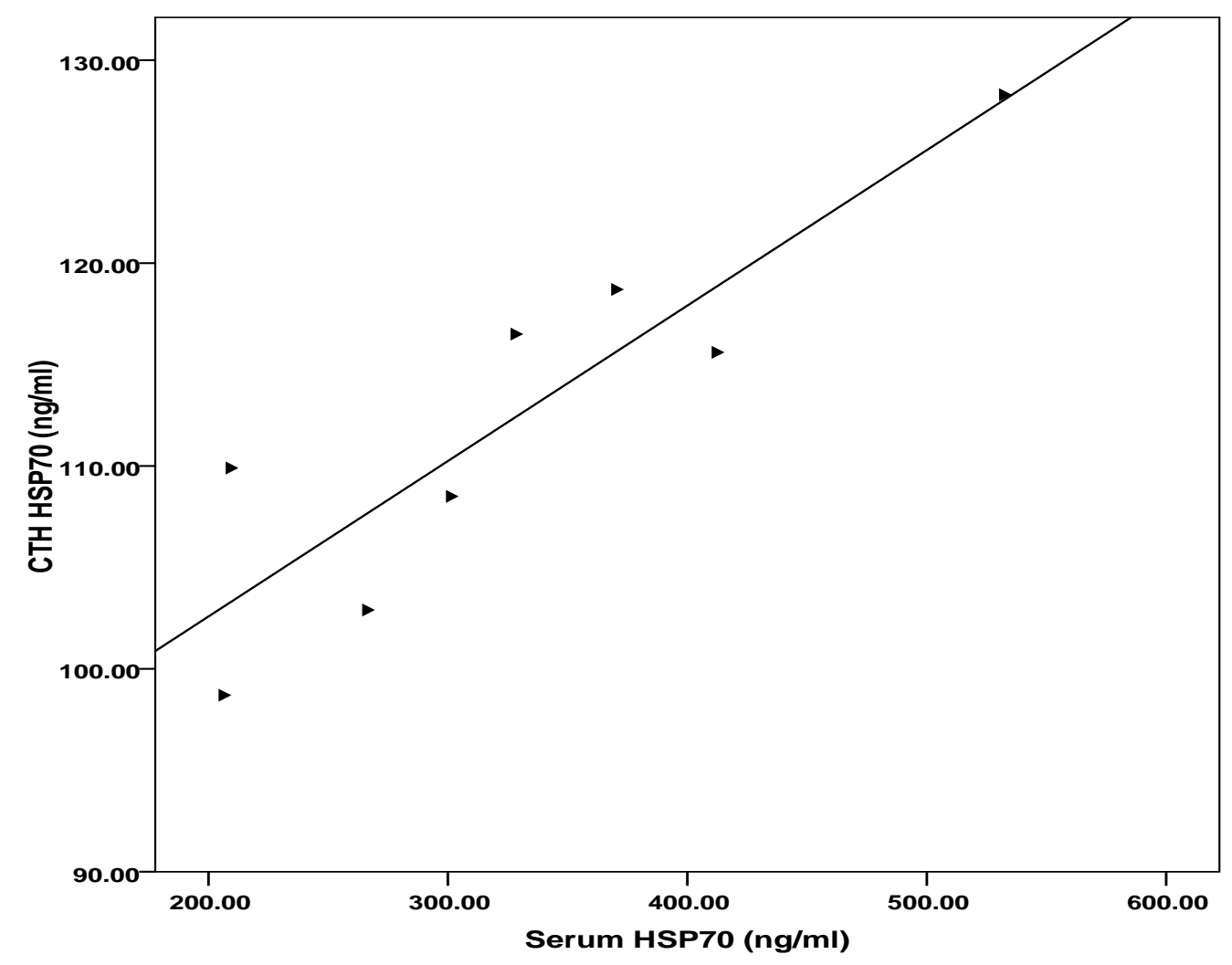

Figure 6: Correlation between HSP70 levels estimated in CTH and serum of animals of control group (Group I)

\section{Discussion}

The current study aimed to evaluate the prophylactic effect of drugs with antioxidant activities on oxidant/antioxidant milieu in cochlear tissue of rats exposed to acute noise trauma (ANT). In line with the rational of the prophylactic use, $\mathrm{Lu}$ et al. [28] documented that pharmacological treatment of noise-induced hearing loss (NIHL) act to protect cochlear sensory cells and afferent neurites from the damaging effects of acoustic trauma. Also, Choi \& Choi ${ }^{[29]}$ documented that antioxidant drugs showed a strong synergistic effect and successful use of antioxidant drugs depends on 
the optimal timing and duration of treatment, which are highly related to the time window of free radical formation induced by noise exposure.

Cochlear tissue homogenate $(\mathrm{CTH})$ of animals exposed to ANT without pre-exposure prophylaxis (Group II) showed significantly higher levels of lipid peroxidation product (MDA) with concomitant significantly lower levels and activities of antioxidants compared to animals not exposed to noise nor received medications (Group I). These findings go in hand with Ersoy et al. ${ }^{[30]}$ who reported that during continued noise exposure, rosuvastatin therapy significantly increased SOD values in the cerebral cortex and brainstem, but significantly reduced MDA values in brain stem. Also, Choi \& Choi ${ }^{[29]}$ documented that the cellular basis of NIHL is oxidative stress manifested as severe disruption in the balance between the production of free radicals and antioxidant defense system secondary to excessive production of free radicals induced by noise exposure. Thereafter, Fetoni et al. ${ }^{[31]}$ detected increased pattern of lipid peroxidation in the organ of Corti with cell damage involving predominantly the outer hair cell $(\mathrm{OHC})$ sensory epithelium in noise exposed cochleae. Recently, Tuerdi et al. ${ }^{[32]}$ detected significantly greater OHC damage in all cochlear turns in SOD heterozygous knockout mice compared with wildtype mice and suggested that SOD plays an important role in protecting the cochlea from noiseinduced damage.

The current study relied on ELISA estimation of HSP70 in both serum and CTH as an indirect quantitative methodology to replace quantitative PCR. Moreover, the current study reported positive significant correlation between HSP70 levels in both CTH and serum, thus indicating accuracy of estimated serum HSP70 levels to reflect its levels in the target tissue exposed to stress and thus could be used as a minimally invasive modality. In line with these data and assumption; Chebotareva et al. ${ }^{\text {[33] }}$ using ELISA estimation of HSP70 found patients with active chronic glomerulonephritis (CGN) have higher excretions of urinary HSP70 and serum antiHSP70 antibodies and concluded that HSP70 is an index of severity of CGN and could assess its prognosis. Gunaldi et al. ${ }^{[34]}$ found the sensitivity and specificity of elevated ELISA estimated serum HSP70 in colorectal carcinoma patients were 96.77 and $96.96 \%$, respectively and its levels were significantly higher with rectal disease localization. In another trial, Gunaldi et al. ${ }^{[35]}$ also documented that ELISA estimation of serum HSP70 can be used as an adjunct to other diagnostic tests for breast cancer and may help for identifying high-risk patients.

Estimated levels of HSP70 in both CTH and serum were significantly higher in animals exposed to ANT without prophylaxis (Group II) compared to group I; a finding indicating increased tissue expression of HSP70 in response to acute noise stress. This finding goes in hand with Balakrishnan et al. [36] who detected significantly higher concentrations of serum HSP70 among frequent users of mobile phones than the infrequent users and its concentration was independent of the duration of exposure to mobile phones.

Moreover, both CTH and serum levels of HSP70 were non-significantly higher in animals received GGA prophylaxis without ANT (Group III), thus indicating the stimulant effect of GGA on tissue expression of HSP70. Interestingly, estimated CTH levels of HSP70 were significantly higher in animals received GGA prophylaxis and exposed to ANT (Group IV) compared to all other groups; thus assuring the reported increased levels in group II and indicated that the stimulant effect of GGA, reported in group III, is intensified on stress exposure. Moreover, GGA prophylaxis could blunt the oxidative stress as reported by the significantly lower MDA and higher antioxidant levels and activity reported in serum of animals of group IV compared to those of group II.

The reported antioxidant properties and HSP70 stimulant effect of GGA coincided with previous studies evaluated GGA prophylaxis against effects of acute stress insults and attributed this effect to its ability to prevent HSP70 degradation ${ }^{[18]}$, for induction of HSP70 ${ }^{[37]}$, or upregulating HSP70 expression ${ }^{[38]}$. Moreover, prophylactic use of GGA through induction of HSP70 expression was documented against various models of ototoxicity $[39,40,41]$. Unfortunately, literature review detected only one trial to evaluate the prophylactic effect of GGA on ANT that reported significantly fewer defects on $\mathrm{OHC}$ in animals given GGA once a day for a week before sound exposure ${ }^{[42]}$. 


\section{Conclusion}

Acute noise trauma induces cochlear tissue oxidative stress; however, prophylactic therapy with GGA protects cochlear tissue through increasing cochlear tissue HSP70 expression levels. ELISA estimation of serum HSP70 levels could reflect its tissue levels and could be used as non-invasive diagnostic modality for impact of stresses. Evaluation of the prophylactic effect of GGA on chronic noise exposure is mandatory to establish its prophylactic role for protection against noiseinduced occupational diseases.

\section{References}

1 Uran SL,Gómez-Casati ME,Guelman LR:Longterm recovery from hippocampal-related behavioral and biochemical abnormalities induced by noise exposure during brain development. Evaluation of auditory pathway integrity. Int J Dev Neurosci. 2014; 37:41-51. https://doi.org/10.1016/j.ijdevneu.2014.06.002

2 Koc ER, Ersoy A, Ilhan A, Erken HA, Sahın S: Is rosuvastatin protective against on noiseinduced oxidative stress in rat serum? Noise Health. $\quad 2015 ; \quad$ 17(74):11-6. https://www.ncbi.nlm.nih.gov/pubmed/255997 $\underline{53}$

3 Cui B, Gai Z, She X, Wang R, Xi Z. Effects of chronic noise on glucose metabolism and gut microbiota-host inflammatory homeostasis in rats. Sci Rep 2016; 6: 36693 DOI: 10.1038/srep36693

4 Sakat MS, Kilic K, Bercin S. Pharmacological agents used for treatment and prevention in noise-induced hearing loss. Eur Arch Otorhinolaryngol 2016; 273(12): 4089-4101 [PMID: 26882913 DOI: 10.1007/s00405-0163936-2]

5 Chang H, Telang RS, Sreebhavan S, Tingle M, Thorne PR, Vlajkovic SM. Pharmacokinetic Properties of Adenosine Amine Congener in Cochlear Perilymph after Systemic Administration. Biomed Res Int 2017; 2017: 8091462 DOI: $10.1155 / 2017 / 8091462$

6 Ryan AF, Kujawa SG, Hammill T, Le Prell C, Kil J. Temporary and Permanent Noise- induced Threshold Shifts: A Review of Basic and Clinical Observations. Otol Neurotol 2016; 37(8): e271-275 DOI: 10.1097/MAO.0000000000001071

7 Le Prell CG, Yamashita D, Minami SB, Yamasoba T, Miller JM. Mechanisms of noiseinduced hearing loss indicate multiple methods of prevention. Hear Res. 2007; 226:22-43.

8 Howe MK, Bodoor K, Carlson DA, Hughes PF, Alwarawrah Y, Loiselle DR, Jaeger AM, Darr DB, Jordan JL, Hunter LM, Molzberger ET, Gobillot TA, Thiele DJ, Brodsky JL, Spector NL, Haystead TA. Identification of an allosteric small-molecule inhibitor selective for the inducible form of heat shock protein 70 . Chem Biol 2014; 21(12): 1648-1659 DOI: 10.1016/j.chembiol.2014.10.016

9 Samborski P, Grzymislawski M. The Role of HSP70 Heat Shock Proteins in the Pathogenesis and Treatment of Inflammatory Bowel Diseases. Adv Clin Exp Med 2015; 24(3): 525-530 [PMID: 26467144 DOI: 10.17219/acem/44144]

10 Cvoro A, Korac A, Matic G. Intracellular localization of constitutive and inducible heat shock protein 70 in rat liver after in vivo heat stress. Mol Cell Biochem 2004; 265(1-2): $27-$ 35 DOI:10.1023/b:mcbi.0000044312.59958.c8

11 Li X, Shao H, Taylor IR, Gestwicki JE. Targeting Allosteric Control Mechanisms in Heat Shock Protein 70 (Hsp70). Curr Top Med Chem 2016; 16(25): 2729-2740 DOI: 10.2174/1568026616666160413140911

12 Kondrikov D, Fulton D, Dong Z, Su Y. Heat Shock Protein 70 Prevents Hyperoxia-Induced Disruption of Lung Endothelial Barrier via Caspase-Dependent and AIF-Dependent Pathways. PLoS One 2015; 10(6): e0129343 DOI: 10.1371/journal.pone.0129343

13 Budina-Kolomets A, Balaburski GM, Bondar A, Beeharry N, Yen T, Murphy ME. Comparison of the activity of three different HSP70 inhibitors on apoptosis, cell cycle arrest, autophagy inhibition, and HSP90 inhibition. Cancer Biol Ther 2014; 15(2): 194199 DOI: $10.4161 / \mathrm{cbt} .26720$

14 Guo R, Ebenezer V, Ki JS. Transcriptional responses of heat shock protein 70 (Hsp70) to thermal, bisphenol A, and copper stresses in 
the dinoflagellate Prorocentrum minimum. Chemosphere 2012; 89(5): 512-520 DOI: 10.1016/j.chemosphere.2012.05.014

15 Inoue $\mathrm{T}$, Yorifuji $\mathrm{N}$, Iguchi $\mathrm{M}$, Fujiwara $\mathrm{K}$, Kakimoto K, Nouda S, Okada T, Kawakami K, Abe Y, Takeuchi T, Higuchi K. Geranylgeranylacetone suppresses colitisrelated mouse colon carcinogenesis. Oncol Rep 2015; 33(4): 1769-1774 DOI: 10.3892/or.2015.3794

16 Umegaki E, Kuramoto T, Kojima Y, Nouda S, Ishida $\mathrm{K}$, Takeuchi $\mathrm{T}$, Inoue $\mathrm{T}$, Tokioka $\mathrm{S}$, Higuchi K. Geranylgeranylacetone, a gastromucoprotective drug, protects against NSAID-induced esophageal, gastroduodenal and small intestinal mucosal injury in healthy subjects: A prospective randomized study involving a comparison with famotidine. Intern Med 2014; 53(4): 283-290 DOI: 10.2169/internalmedicine.53.1572

17 He D, Song X, Li L. Geranylgeranylacetone protects against cerebral ischemia and reperfusion injury: HSP90 and eNOS phosphorylation involved. Brain Res 2015; 1599: 150-157 [PMID: 25514333 DOI: 10.1016/j.brainres.2014.12.019]

18 Koriyama Y, Ogai K, Sugitani K, Hisano S, Kato S. Geranylgeranylacetone Suppresses NMethyl-N-nitrosourea-Induced Photoreceptor Cell Loss in Mice. Adv Exp Med Biol 2016; 854: 237-243 DOI: 10.1007/978-3-31917121-0_32

19 Choi CH, Du X, Floyd RA, Kopke RD. Therapeutic effects of orally administrated antioxidant drugs on acute noise-induced hearing loss. Free Radic Res 2014; 48(3): 264272 DOI: 10.3109/10715762.2013.861599

20 Fujibayashi T, Hashimoto N, Jijiwa M, Hasegawa Y, Kojima T, Ishiguro N. Protective effect of geranylgeranylacetone, an inducer of heat shock protein 70, against drug-induced lung injury/fibrosis in an animal model. BMC Pulm Med 2009; 9: 45 DOI: 10.1186/14712466-9-45

21 Albuquerque AA,Rossato M, Oliveira JA, Hyppolito MA: Understanding the anatomy of ears from guinea pigs and rats and its use in basic otologic research. Braz J Otorhinolaryngol.2009;75(1):43-9.
https://doi.org/10.1016/S1808-

8694(15)30830-2

22 Lash LH, Jones DP: Distribution of oxidized and reduced forms of glutathione and cysteine in rat plasma. Arch Biochem Biophys. 1985; 240(2):583-92. https://doi.org/10.1016/00039861(85)90065-7

23 Armstrong D, Brown R: Free radicals in diagnostic medicine. 1994, 366; 43-58. https://www.ncbi.nlm.nih.gov/pubmed/777128 $\underline{1}$

24 Ursini F, Maiorino M, Gregolin C: The Selenoenzyme phospholipid hydroperoxide glutathione peroxidase. Biochim. Biophys. Acta, $\quad$ 1985; $\quad 839$ : 62-70. https://doi.org/10.1016/0304-4165(85)90182-5

25 Johansson LH,Borg LAH:A spectrophotometric method for determination of catalase activity in small tissue samples. Anal. Biochem., 1988; 174: 331-6. $\quad$ https://doi.org/10.1016/00032697(88)90554-4

26 Marklund S: Distribution of CuZn superoxide dismutase and $\mathrm{Mn}$ superoxide dismutase in human tissues and extracellular fluids. Acta Physiol. Scand., 1980; Suppl. 492: 19-23. https://www.ncbi.nlm.nih.gov/pubmed/693930 $\underline{5}$

27 Munari L, Charchat S,Rodrigues L, von Muhlen CA, Baú AR, Lavinsky L, Bonorino C: An ELISA serum assay for autoantibodies to HSP70 in immune-mediated hearing loss. $\boldsymbol{J}$ Immunol Methods. 2003; 283(1-2):155-61. https://doi.org/10.1016/j.jim.2003.09.008

28 Lu J, Li W, Du X, Ewert DL,West MB, Stewart C, Floyd RA, Kopke RD: Antioxidants reduce cellular and functional changes induced by intense noise in the inner ear and cochlear nucleus. J Assoc Res Otolaryngol. 2014; 15(3):353-72.

http://dx.doi.org/10.1007/s10162-014-0449-9.

29 Choi SH, Choi CH. Noise-Induced Neural Degeneration and Therapeutic Effect of Antioxidant Drugs. J Audiol Otol 2015; 19(3): 111-119 DOI: 10.7874/jao.2015.19.3.111

30 Ersoy A, Koc ER, Sahin S, Duzgun U, Acar B, Ilhan A. Possible effects of rosuvastatin on noise-induced oxidative stress in rat brain. Noise Health 2014; 16(68): 18-25 [PMID: 24583676 DOI: $\underline{10.4103 / 1463-1741.127849]}$ 
31 Fetoni AR, Rolesi R, Paciello F, Eramo SLM, Grassi C, Troiani D, Paludetti G. Styrene enhances the noise induced oxidative stress in the cochlea and affects differently mechanosensory and supporting cells. Free Radic Biol Med 2016; 101: 211-225 DOI: 10.1016/j.freeradbiomed.2016.10.014

32 Tuerdi A, Kinoshita M, Kamogashira T, Fujimoto C, Iwasaki S, Shimizu T, Yamasoba T. Manganese superoxide dismutase influences the extent of noise-induced hearing loss in mice. Neurosci Lett 2017; 642: 123-128 DOI: 10.1016/j.neulet.2017.02.003

33 Chebotareva NV, Neprintseva NV, Bobkova IN, Kozlovskaia LV: Investigation of $70-\mathrm{kDa}$ heat shock protein in the serum and urine of patients with chronic glomerulonephritis. Ter Arkh. 2014; 86(6):18-23. https://www.ncbi.nlm.nih.gov/pubmed/250956 $\underline{51}$

34 Gunaldi M, Kocoglu H, Okuturlar Y, Gedikbasi A, Karabulut M, Alis H, Hursitoglu M: Heat shock protein 70 is a useful marker for predicting colorectal cancer. J BUON. 2015; 20(6):1464-70. Kocoglu H , 0000-0002-92082693

35 Gunaldi M, Afsar CU, Okuturlar Y, Gedikbasi A, Kocoglu H, Kural A, Akarsu C, Gunduz U, Tiken EE. Elevated serum levels of heat shock protein 70 are associated with breast cancer. Tohoku J Exp Med 2015; 236(2): 97-102 [PMID: 26018606 DOI: $10.1620 /$ tjem.236.97]

36 Balakrishnan K, Murali V, Rathika C, Manikandan T, Malini RP, Kumar RA, Krishnan M. Hsp70 is an independent stress marker among frequent users of mobile phones. J Environ Pathol Toxicol Oncol 2014; 33(4): 339-347 [PMID: 25404380]
37 Cao W, Li M, Li J, Li C, Xu X, Gu W. Geranylgeranylacetone ameliorates lung ischemia/reperfusion injury by HSP70 and thioredoxin redox system: NF-kB pathway involved. Pulm Pharmacol Ther 2015; 32: 109-115 DOI: 10.1016/j.pupt.2015.02.009

38 He W, Zhuang Y, Wang L, Qi L, Chen B, Wang M, Shao D, Chen J. Geranylgeranylacetone attenuates hepatic fibrosis by increasing the expression of heat shock protein 70. Mol Med Rep 2015; 12(4): 4895-4900 DOI: $\underline{10.3892 / \mathrm{mmr} .2015 .4069}$

39 Sano H, Yoneda S, Iwase H, Itoh A, Hashimoto D, Okamoto M. Effect of geranylgeranylacetone on gentamycin ototoxicity in rat cochlea culture. Auris Nasus Larynx 2007; 34(1): 1-4 [PMID: 16934423 DOI: $10.1016 / \mathrm{j}$. anl.2006.05.020]

40 Yin HY, Ma XF, Liu F, Xia M, Xu AT. Protective effect of geranylgeranylacetone on cisplatin ototoxicity. Chemotherapy 2009; 55(1): 1-5 DOI: $10.1159 / 000166382$

41 Kim YH, Song JJ, Kim YC, Park KT, Lee JH, Choi JM, Lee JH, Oh SH, Chang SO. Geranylgeranylacetone ameliorates acute cochlear damage caused by 3-nitropropionic acid. Neurotoxicology 2010; 31(3): 317-325 DOI: $10.1016 /$ j.neuro.2010.03.001

42 Mikuriya T, Sugahara K, Takemoto T, Tanaka $\mathrm{K}$, Takeno K, Shimogori H, Nakai A, Yamashita H. Geranylgeranylacetone, a heat shock protein inducer, prevents acoustic injury in the guinea pig. Brain Res 2005; 1065(1-2): 107-114 DOI: 10.1016/j.brainres.2005.10.045 